Laura LACHVAJDEROVÁ ${ }^{1}$, Jaroslava KÁDÁROVÁ², Marek MIZERÁK ${ }^{3}$, Ján KOPEC ${ }^{4}$

Supervisor: Peter TREBUŇA ${ }^{5}$

DOI: https://doi.org/10.53052/9788366249837.34

\title{
PRZEGLĄD POSTACI ROBOTÓW GRAJĄCYCH W FOOTBALL STOLOWY
}

Streszczenie: Artykuł ten dotyczy idei footballu stołowego robotów w ujęciu ogólnym. Dokonano chronologicznego przeglądu dostępnych, istniejących rozwiązań oraz zestawiono ich indywidualne historie. Ponadto, skrótowo opisano jak działają zestawy z footballem stołowym robotów. Zestawiono także zalety i wady omówionych rozwiązań. Na zakończenie artykułu dokonano oceny, i równocześnie, analizowano możliwe modyfikacje - aby osiągnąć zupełnie automatyczne systemy footballu stołowego robotów dla wybranych, poszczególnych rozwiązań.

Słowa kluczowe: football stołowy robotów, istniejące rozwiązania, zalety i wady

\section{OVERVIEW OF DEVELOPED ROBOTIC TABLE FOOTBALL SOLUTIONS}

Summary: This article focuses on table football in general. It points to a chronological overview of the developed solutions and their history, to a brief description of how robotic table football works and in the end to describe the advantages and disadvantages of the solutions. At the end of the article, the overall solutions are evaluated and at the same time, possible modifications for the complete automation of robotic table football in the individual developed solutions are presented.

Keywords: robotic table football, developed solutions, prons and cons

\footnotetext{
${ }^{1}$ Technical University of Kosice, Faculty of Mechanical Engineering, Department of Industrial and Digital Engineering; laura.lachvajderova@tuke.sk

${ }^{2}$ Technical University of Kosice, Faculty of Mechanical Engineering, Department of Industrial and Digital Engineering; jaroslava.kadarova@tuke.sk

${ }^{3}$ Technical University of Kosice, Faculty of Mechanical Engineering, Department of Industrial and Digital Engineering; marek.mizerak@tuke.sk

${ }^{4}$ Technical University of Kosice, Faculty of Mechanical Engineering, Department of Industrial and Digital Engineering; jan.kopec@tuke.sk

5 prof. Ing. PhD., Technical University of Kosice, Faculty of Mechanical Engineering, Department of Industrial and Digital Engineering; peter.trebuna@tuke.sk
} 


\section{Introduction}

Machinery is a common part of everyday life. However, a major breakthrough in the use of these devices was brought about by the industrial revolution. People's responses to change have been diverse. Some saw machines as a threat, others as a chance and an opportunity to make life easier. Nowadays, we can talk about a similar situation, but this time in connection with intelligent machines and their processes. The socalled ubiquitous revolution will take us where machinery can be installed really everywhere, for example in the human body, robots as helpers will be a common part of every household, and we can undoubtedly say that robots will become companions for lonely people. However, new technologies not only bring new benefits and opportunities but also come with new costs and threats. The pace at which the industrial revolution has begun is becoming more and more unstoppable, and the future may seem like a big unknown to us. Every week, new innovations and inventions are introduced, as a result of which there is a need for constant education in the field. Nowadays, the automation of almost all devices and processes has become a big trend. Even the most popular area of people, such as entertainment and sports, did not escape this.

Table football, which belongs to the category of board games, definitely belongs to the group of the most popular entertainment and at the same time sports. However, many people still think that it has nothing to do with sport, but in 2002 it was recognized by the establishment of the International Table Football Federation (ITSF), whose main mission is to promote table football as a sport and also to be included among the Olympic disciplines in cooperation with the International Olympic Committee and the International Sports Federation [1].

\section{Developed solutions}

In the last few years, this area has grown significantly compared to the following years (Fig. 1). The quality has improved, whether in the case of a software or hardware solution. Much of the solution was developed on the grounds of universities around the world in order to prepare final theses at various levels of study.

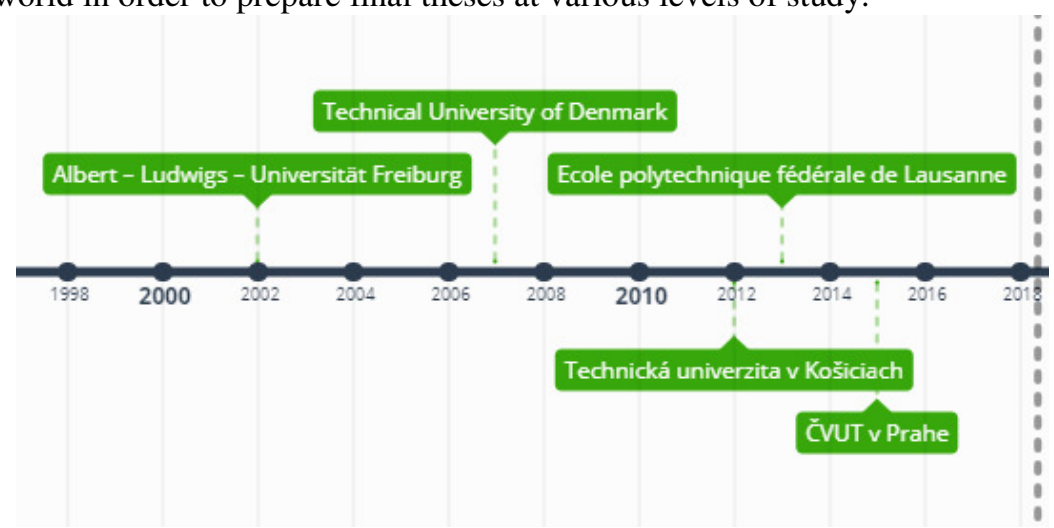

Figure 1. Timeline of developed solutions, Source: Own research 
One of the first robotic table football (RTF) solutions was developed at the University of Freiburg in Germany. The aim of the game strategy is to take pictures of the playing area with a high-frequency camera located above the playing area, which captures the position of the ball and also the position of the players. The entire cycle in which this detection takes place takes 20 milliseconds. This time includes data processing and system feedback [2]. However, the disadvantage of the camera being located above the playing area is the possibility of the player shielding the ball during the game. However, this problem has been solved by assigning the last known position of the ball to the nearest player in this case and then placing all players in the field in the basic position as at the beginning of the game. In 2005, this mechanism and design were modified by Gauselman AG to a subsequent form (Fig. 2), where the designers focused mainly on safety when manipulating in the playing field [3].

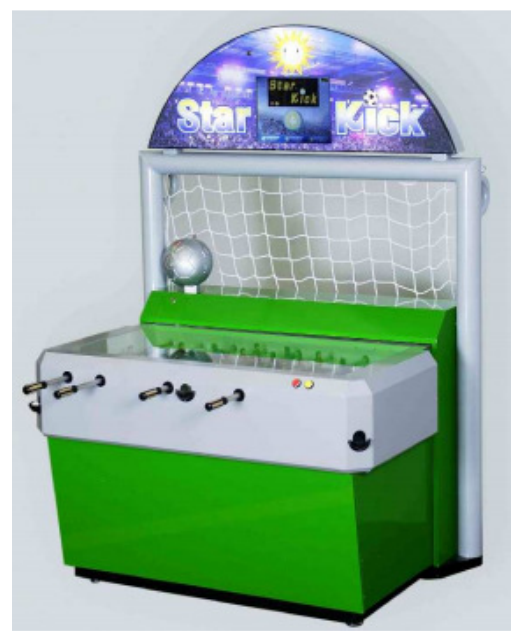

Figure 2. Final form of RTF from Gauselman AG, Source: [3]

Constructed RSF at the Ecole polytechnique fédérale de Lausanne in Switzerland by students and teachers can be divided into two parts. The first version dates from 2013 and was made by a pair of Martin Savary and Cyril Picard, which focused mainly on the dynamic movement of the axis. The first servomotor is located to the sliding axis, is connected by a belt to a gear wheel and is thus connected to a fixed table structure. A sliding support is connected to the belt, on which the second servomotor is placed. The position of the ball is detected by a camera located at the bottom of the table [4]. However, the pair of designers did not focus on detecting the opponent's position in this solution.

The second version from 2016, in which student Léo Sibut and Dr. Christophe Salzmann, has been improved with greater speed and accuracy. This pair was the first to come up with a solution for detection using laser sensors, and their game strategy was supplemented by the detection of the opponent's position. The principle of detecting the position of the game axis is to detect two distances. At the end of each opponent's axis, there are snail-shaped plastic handles. The front of the shaft is flush and level with the first laser sensor. The detected distance does not change during rotation. However, due to the rotation between the sensor and the handle, the distance 


\section{Laura LACHVAJDEROVÁ, Jaroslava KÁDÁROVÁ, Marek MIZERÁK, Ján KOPEC}

measured by the second sensor changes. The difference between these distances determines the angle of rotation, which can be calculated based on the pitch of the shaft [5]. Linear motion is controlled by dynamic motors with an accuracy of less than $1 \mathrm{~mm}$ and can generate acceleration of up to $9 \mathrm{~g}$, which means that they provide much higher speeds than a human player can. The rotary motion is taken care of by a rotary servomotor. The detection of the ball is provided by a camera, which is located under the playing surface of table football. The camera detects a colored ball visible through the transparent playing field and can produce up to 300 frames per second. (Fig. 3) With the help of these images, the system evaluates and processes its own image and with the help of lasers that detect the opponent's position, the system evaluates, based on the obtained data, the best way to score to the opponent's goal [5].

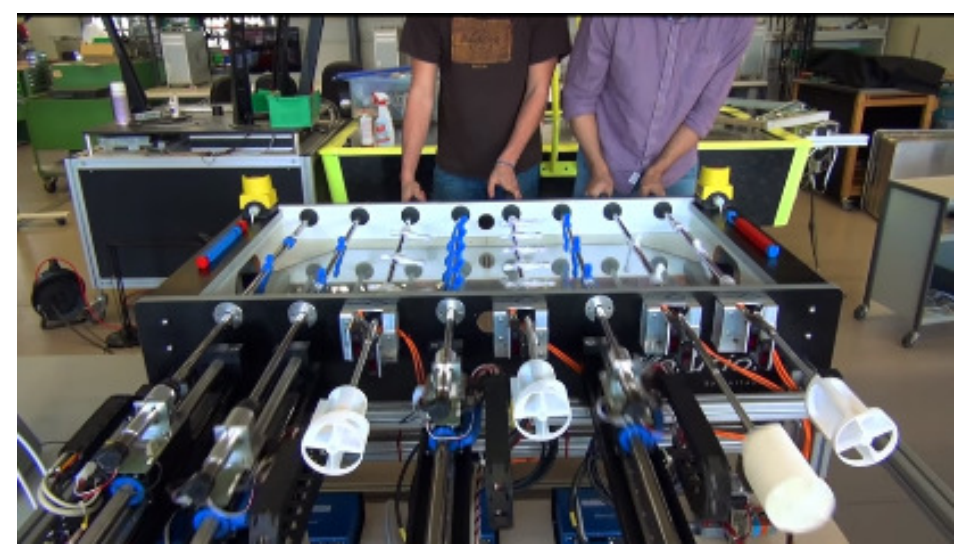

Figure 3. EPFL - Robotic table football, Source: [5]

Among other universities, we have the Technical University of Denmark, which officially ended the development of the RSF in 2007. The project was fully functional and ready to compete with a human opponent. The table has all four axes automated on one side. The drive is provided by two rotary motors located on one side of the table. One motor provided linear motion and the other motor rotary motion.

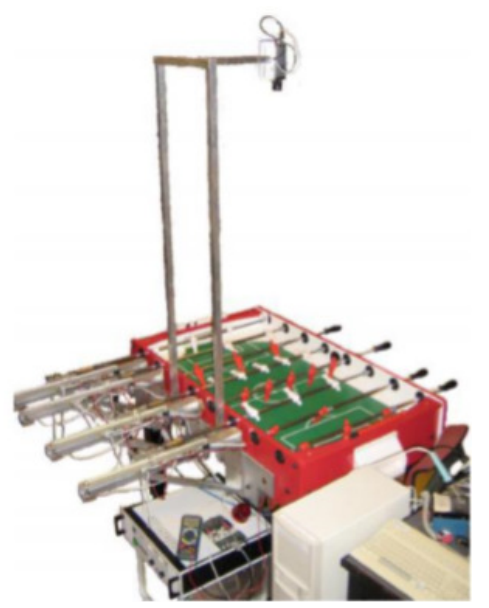

Figure 4. RSF made at the Technical University of Denmark, Source: [6] 
In Figure 4 we can see that the whole structure is massive and heavy. The general principle of the solution of this type of RSF is very similar to the solution given by the University of Freiburg. It is also a camera located above the playing area, which captures the position of the ball. The camera used in this solution sends images to a computer at a rate of 25 frames per second. Until this time, the data processing time is already included. The aim of this solution was mainly simple assembly and disassembly of the whole system. According to the available information, this whole solution is able to compete with a human opponent [6].

The Department of Cybernetics and Artificial Intelligence at the Technical University in Kosice (TUKE) in the years 2012 - 2014 participated in the production of a smaller version of robotic table football. Even since the technical means for making the RSF are not a cheap affair, TUKE provided material for the production and modification of table football for only two-game bars. The RSF model is located in the main TUKE building in the L9-536 / A laboratory (Fig. 5). The construction is very similar to the model from Denmark. The camera is placed above the playing area and captures the ball. Servomotors are located on the two-game bars, which perform sliding and at the same time rotary movement. This whole system is complemented by a computer, which controls the modified rods using an algorithm and moves them so as to prevent the opponent from scoring and at the same time to place the ball in the opponent's goal. Since the playing area is much smaller than the usual one, the game runs very fast [7].

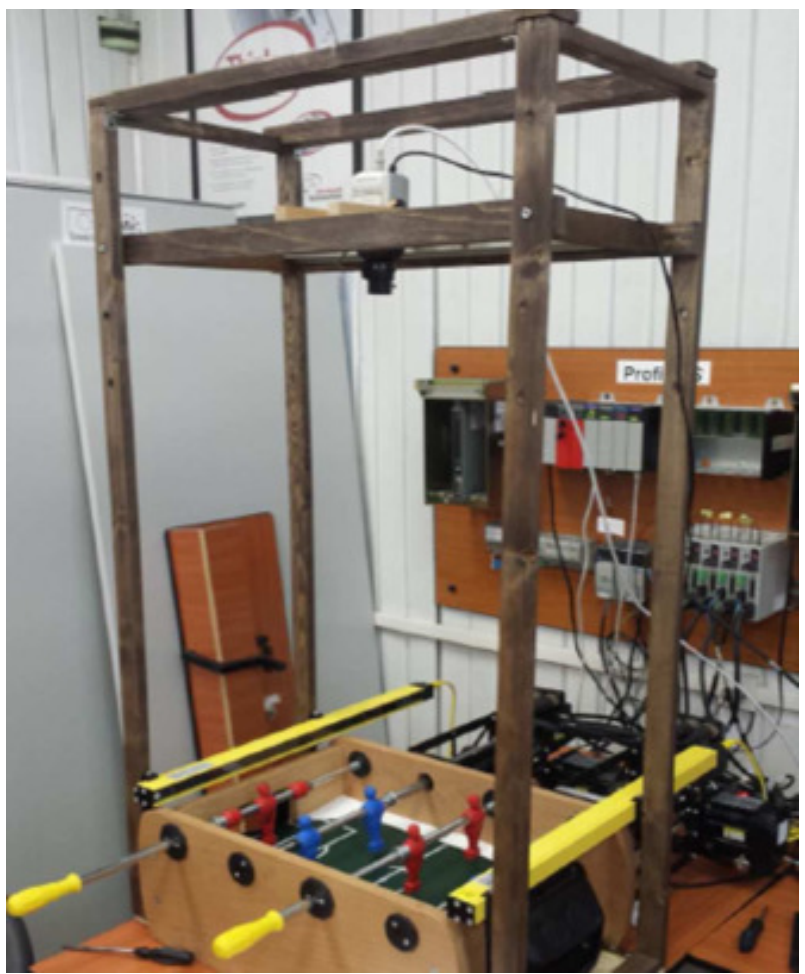

Figure 5. RSF model at TUKE, Source: [7] 


\section{Prons and cons of developed solutions}

The above-mentioned descriptions of robotic table football point to what needs to be done for their creation and implementation. Everything has its advantages and disadvantages, and this certainly applies to the mentioned developed solutions. One of the first disadvantages would certainly be the load of the RSF scanning camera in Freiburg. The speed at which the camera processes the acquired images decreases due to a large amount of received data. This reduces the response speed of the control system itself. The Technical University of Denmark provided us with a very similar solution to the University of Freiburg. As a clear disadvantage of the models at the universities of Freiburg and Denmark, we would definitely include a camera located above the playing area. Since the axis of rotation has two positions, the camera cannot recognize whether the player is pointing down or up. In this case, the control system must assume that the player's position is downwards, thus preventing the ball from passing, although in reality, it may be the other way around when the ball has no problem passing through the player (Fig. 6).

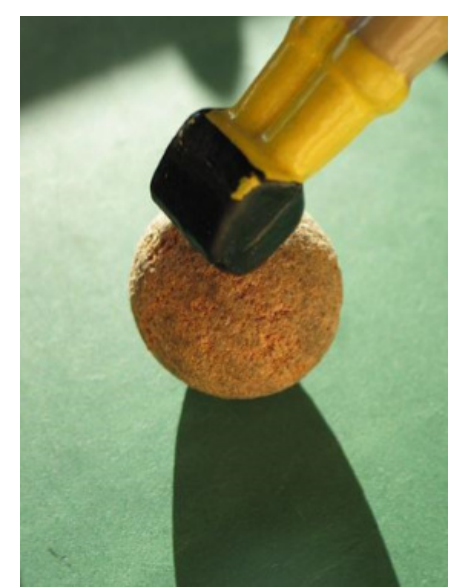

Figure 6. Ball in line with a player, Source: [8]

EPFL in Switzerland has developed two solutions. While in the first solution they did not focus on the detection of the opponent's position, in the second solution they improved it by laser scanning of his position and also increased the speed and accuracy of the whole system. I consider it a great advantage that the camera is placed under a transparent playing field, so the problem that was mentioned in the model of a university from Denmark does not arise. Last but not least, a model made on TUKE, which shows that one can invent in every adverse situation. The fact that the funds provided were not ideal did not stop the students from bringing the model to the final version. Although it is a model with a camera located above the playing area, in this case, I see as a clear advantage the determination of students to reduce the playing area, to deal with the design and development of the algorithm and especially to adapt their capabilities to what was provided [9]. 


\section{Conclusion}

Based on these developed solutions, we learned how robotic table football works and described ways to perform automation of table football, the use of drives, control unit and all components that are needed for the implementation of robotic table football. We have given several examples of developed solutions, their shortcomings and, conversely, their benefits. Every year, robotics and automation move forward by leaps and bounds, so in terms of future prospects, it is necessary to focus on current technological procedures and innovations in individual areas. It is important to focus on creating the right algorithm, choosing the right control unit and choosing the right camera. The pace set by the industrial revolution has become more and more unstoppable, and the future of robotic football at such a pace may not seem one-sided due to technological innovations that appear periodically in the fields of automation and robotics.

\section{Acknowledgement}

This article was created by the implementation of the grant project APVV-17-0258 "Digital engineering elements application in innovation and optimization of production flows", APVV-19-0418 "Intelligent solutions to enhance business innovation capability in the process of transforming them into smart businesses", VEGA 1/0438/20 "Interaction of digital technologies to support software and hardware communication of the advanced production system platform”, KEGA 001TUKE-4/2020 "Modernizing Industrial Engineering education to Develop Existing Training Program Skills in a Specialized Laboratory", VEGA 1/0340/21 "The impact of a pandemic and the subsequent economic crisis on the development of digitization of enterprises and society in Slovakia" and KEGA 009TUKE-4/2020 "Transfer of Digitization into Education in the Study Program Business Management and Economics".

\section{REFERENCES}

1. ITSF STRUCTURE: Our Goals. Available at: https://www.tablesoccer.org/page/our-goals.

2. WEIGEL, T. KiRo - An autonomous table soccer player. Available at: http://gki.informatik.uni-freiburg.de/papers/weigel-etal-robocup-02-kiro.pdf.

3. WEIGEL, T. KiRo - A Table Soccer Robot Ready for the Market. Available at: http://www2.informatik.uni-freiburg.de/ ki/papers/weigel-ki2005.pdf.

4. RIDDEN, P. It's only a game: Robots defeat humans on foosball playing field. New Atlas. Available at: https://newatlas.com/epfl-robot-table-soccerfoosball/44863/.

5. All brawn, little brains, EPFL students 'table-football robot: EPFL News. Available at: https://www.youtube.com/watch? $v=-r h X x 0 d J A 2 M$.

6. Automated foosball table: A project at DTU. Available at: http://foospmp.myl.dk/. 
7. DURKAJ, P. Design and creation of robotic table football player control algorithms: Diploma thesis. Košice: Technical University of Košice, Faculty of Electrical Engineering and Informatics, 2014. 65p. [online].

8. DOCTEUR, Cosmos: Table football ball close-up. Available at: https://commons.wikimedia.org/wiki/File:Table_football_ball_close-up_1.jpg.

9. LACHVAJDEROVÁ, L. Robotic Table Football. Košice, 2018. Bachelor thesis. Technical University of Kosice. 